\title{
Interpretation of Power: A Comparison Between Christian-based West and Confucius-based East
}

\author{
Yingying $\mathrm{Du}^{1, *}$ \\ ${ }^{1}$ College of Social Science, Australian National University, Canberra, ACT, Australia \\ *Corresponding author. Email: guanghua.ren@gecacademy.cn
}

\begin{abstract}
Mainstream IR theories are largely western-focused and little attention has been paid to theories from other parts of the world. With the development of IR discipline in China, many scholars tend to form a 'Chinese School'. However, the rise of China is often seen as a threat by the West, yet the Chinese way of thinking is often undervalued therefore causing many clashes of civilizations between the West and the East. This essay aims to compare how the West and the East vary in interpreting power, and the reason behind such variation. In order to do so, this essay compares political philosophy between the West and the East to demonstrate that the mainstream IR theories today are highly influenced by Christian traditions. They went through a secularisation process to make it more acceptable. Yet, compared with Confucian-influenced East, although it is not a religion, it still exerts impacts on Chinese society. After comparing philosophies from Hobbes, Rousseau, Locke with Confucius, Mencius and other Confucian ideas, this essay argues that the West and the East have fundamentally different perceptions of power. The West usually regards power and analyzes it from a 'bottom-up' way, while the East focuses on the macro-level of power and often analyses from up to bottom. Finally, this essay later uses Foucault's interpretation of power as an empirical analysis while Fei Xiaotong's model is an example from the East.
\end{abstract}

Keywords: Christianity, Confucianism, Power

\section{INTRODUCTION}

The paradigm of western International Relations theory is rooted in its historical and political practice, and its logical basis and philosophical system are 'westernized' through the secularisation of Christian tradition [1]. On the other hand, the development of China's International Relations theory has gone through a long process from the pre-theoretical stage to a formal theoretical proposal. During this process, the theoretical paradigm of American scholars was the mainstream at first, and then the "English school" was gradually developed in Europe [2]. However, the "English school" cannot be separated from the European cultural homogeneity, and its universality is questionable [3]. The "Chinese school" proposes theories with "Chinese characteristics" yet there are plenty of Western elements within it [1]. Many Chinese scholars try not to put Western elements while establishing their theories and try to use traditional Chinese thoughts to explain phenomena and concepts.
This essay aims to compare how the West and the East vary in interpreting power, and the reason behind such variation. Therefore, this essay argues that the fundamentally different perceptions about power are due to the Christian and Confucians traditions in the West and China respectively. This essay will first compare and explain the Christian and Confucians traditions then compare the differences. Finally, this essay will use Foucault's s work as a representation of Christian-based analysis of power, while Fei Xiaotong as a representation of Confucian traditions to demonstrate this difference.

\section{CHRISTIANITY VERSUS CONFUCIANISM}

To begin with, although the binary categorization of the 'West' versus the 'East', Christianity versus Confucianism, is largely criticized as being rather simplistic, in the discipline of IR theory it is still fair and important to make such generalization due to the predominant position of American theories and arguably, Eurocentric traditions, and thus the lack of Southern theories [4]. Through historical progression, together 
with the changes, and amendments of societies, the 'West' today is far from the traditional definition of Christian society. However, the post-modernist multicultural norm stemmed from Christian traditions [5]. Even though there are critiques against Christianity from Enlightenment philosophers like Marx, Nietzsche, to modern existentialists like Camus and Sartre, such criticisms show how deeply Europe - or the West - has deep roots in Christianity [6]. Moreover, with Enlightenment, Christian traditions have been transformed into political ideologies. For example, the core concepts of the Declaration of the Rights of Man and the Citizen from 1789, or the national motto of France: Liberty, Equality, Fraternity, are secularized Christian ideas that emerged during the antagonism with the Church [2]. These secularized Christian-based concepts include individualism, rationalism and a scientific approach to social science that pushed Western-styled modernization. With colonialization and the success of modernization, development theorist like Rostow developed a linear progression theory to explain modernization. In his theory, five stages of development transform nations from traditional society to the stage of mass consumption [7]. Such linear progression has become the 'right' way to modernization and many societies weakened the role of their traditional philosophy and regard this Westernstyled modernization as the only solution to prosperity [8].

In addition, Western political philosophers' understanding of 'the State of Nature' is largely derived from the Christian way of interpreting human nature. State of nature is the hypothetical condition before humans join any political association or engage in any social and political activities. Hobbes in his work Leviathan describes human life as 'solitary, poor, nasty, brutish and short'. Therefore, the 'state of nature' is a 'state of war', that human is inherently evil and prefer conflict rather than cooperation [9]. On the other hand, Rousseau criticizes Hobbes's conception of State of Nature that filed with social antagonism. For Rousseau, the state of nature is only a primitive state before socialization, therefore there are no conditions for human to have emotions like pride, envy, or fear for other humans [10]. Therefore, the state of nature is a peaceful condition that human only act based on their natural urges and desires like hunger and self-preservation. Although Hobbes and Rousseau take two extreme stands on human nature, they stand on the extreme ends of the dualistic nature that Christians argues about human nature.

Moreover, many Christian traditions have been preserved in a more secular form after the religious roots are weakened and faded during the historical process of modernity. For example, the universal missionary zeal is an essential part of Christianity, and it has been preserved and transformed into a secular and civic 'religion': liberalism, Marxism, capitalism, and then democracy and the pursuit for human rights [5]. The roots for human rights come from the idea of human dignity and the divine position of the natural law, which can be traced back to the Christian traditions. Some of the radical assertions have become a new form of secular doctrine which has an extreme, quasi-religious tendency. An example would be John Locke's work the Second Treaties on Government. Unlike Hobbes, Locke argues that men have naturally endowed with rights to life, liberty, and property, and therefore, the state of nature is peaceful [11]. Yet, the foundation of his assumptions is human's belief in God. In other words, Christianity is the cornerstone of his philosophy. However, without this cornerstone, Locke's theory still has an important role in modern IR theory because in his theory, once a man leaves this Christian-based state of nature, they are secularised into a commonwealth that they all agree on. The commonwealth has impartial power and is capable of arbitrating conflicts and disputes [11]. As such, civil society is established. Locke's theory has influenced the American Revolution and more generally, gave birth to the modern liberalism that dominates today's IR [2]. Breaking the balance of this dominating Christian-based international order would lead to two reactions. The first is those who emphasize material goods, social progress, democracy, human rights, and free trade focus on its positive side that Christian traditions and its thinking are more popular than their military or strong economy with modernization process. However, the negative side is that such focuses led to colonialism, imperialism, and various forms of genocides. Along with the rapid economic growth are the environmental damages that should not be ignored [5].

In conclusion, although most of the Christian thoughts and traditions are secularized into an unidentifiable form, it is still the base that formed Western society, therefore, it is suitable to call it postChristian values. Moreover, such values have been spread to the world with colonialism and then popularised with military and technology development. Yet the similarity is that these values share the same early-Christian missionary passion.

\section{CONFUCIANISM AND CHRISTIANITY'S INFLUENCES}

Confucianism and Christianity have both positive and negative influences on East Asian societies and Western societies respectively. Although Confucianism is strictly not a religion and is historically different from Christianity, it serves the same function as religious faiths. For the past 2000 years in Chinese history, the Confucian version of universal values, such as 'the world is for all' and the concept of 'unity of man and nature', have exerted a profound influence in China and other countries in the East [12]. However, Confucian universal values lack the missionary fervour that Christianity 
advocates for. Instead, Confucianism advocates for a harmonious social and moral order that is widely accepted and practiced in East Asia [13]. Unlike the Christian church, although Confucianism as a political mechanism disappeared with the fall of feudalism, it remains to some extent the ethical foundation of Chinese society as a post-Confucianism era [5].

As mentioned above, under the advocacy of rationalism and science, European Enlightenment philosophy got rid of the superstition of Christian faith in the 18th century, which promoted and catalyzed the secularisation of Christianity. For the first time, Church and the state are separated and step by step, the Church is marginalized [2]. Confucianism as well has been largely criticized as a dominating foundation and baseline for social and legal practices during the May 4th Movement. It was argued that Confucianism was held responsible for the 'illnesses' that appeared in traditional Chinese society [13]. Moreover, many have argued that from a social Darwinian point of view, Confucianism is also blamed for China's lagging economy, technology, and military development [14]. Yet, unlike Christian, Confucianism outlived these criticisms even though many of them are justified. The reason is that Confucianism did not go through the process of secularization. As a form of social, political, and ethical thought, Confucianism itself is a secular way of thinking. It does not have the supernatural and legendary content that Christian possesses that makes it hard for the modern world to accept. Therefore, Confucianism survived after anti-tradition events and even the Cultural Revolution [14]. Both Christian and Confucianism represent the best and the worst of their traditions. Their meanings, positive or negative, are often based on ideological inclinations during the historical process. Here, the focus will be on the more positive side of Confucianism as it has shown that the complete abandonment of Confucianism also had negative consequences.

One of the central concepts of Confucianism is to place individuals in multiple circles of relations [15]. Such relations, for example, can be the hierarchical relationship between employees and the employer at work, or a relationship among friends, within nations and the universe. Such interrelationship is characterized by a sense of mutual assistance, responsibility, and obligation. Therefore, the mission of Confucianism, according to Fan Zhongyan, is to be 'the True Man' that regards governing of the nation as his own duty [14]. The way to social harmony, or even universal harmony, is, to begin with, the individual 'self', and to end with the transcendence of this 'self'. The 'self' here does not simply mean individuals, it is also for the family, the group, and the nation [5]. Such ideas are also present in Daxue. Fung argues that, on one hand, it is a doctrine with the secular context of human relations, on the other hand, the emphasis of Chinese traditional philosophy is to pursue a superior way of life, but such way of life does not diverge from the everyday life that people are living now [15]. Therefore, the goodness that individuals pursue is also applicable to others. Lun Yu explains such an idea as the man with the perfect virtue wants to establish not only himself but also seeks to establish others [2]. Each individual finds himself in a web of relationships. Thus, to recognize the good in daily life is to be 'benevolent' [16]. Unlike the Christian fraternity, this Confucian social value is not an absolute, universal value that applies to all, but has a specific focus on 'father-son love'. Mencius explains that 'father-son love' is a basic but universal experience that can be expanded and extended to the whole world, yet filial piety between parents and children still plays an important role [5]. In short, Confucianism is characterized as an ethical-based self-cultivation and self-transcendence. It emphasizes mutual obligations, family values and relationships.

As the ideological system of the ruling class, Confucianism not only has an ethical and religious function but also has a political function. Its political ideas are derived from Mencius and Da Xue. Mencius' main political creed was "benevolent governance", concerned with the welfare of the people, and the ruler's welfare is the least important. The political creed of Da Xue is a combination of morality and politics: people in charge of public affairs should model moral behavior through self-cultivation and have a sense of social responsibility. In history, this led to meritocracy, which selects intellectual elites as rulers that can participate in politics through examinations. However, from a modern liberal democracy point of view, due to its hierarchical structure, it has disadvantages such as the rigidity of its format during Qing Dynasty. Confucianism encourages intellectual meritocracy, regulations by ethics and conscience, through the 'middle way' to achieve a universally good and harmonious social order [17]. Therefore, Chinese society is seen as a family and competition for individual interests is harmful to social harmony. Thus, intellectual elites who oversee governing matters are unlikely to stand up against the government, but rather, they should have parental kindness and care towards the next generation [17]. As a result, governing processes tend to be untransparent. Firstly, because there is no need for the general public who is ignorant about politics compared to the elites to get involved. This would increase efficiency. Secondly, there is no need for the public to balance the government because the government is like parents taking care of the public like children. Contrasting the West, where the social contract is the dominant value that individuals have the ability and rational enough to adjust between their interests and conflicts. The social contract that the Western society holds up to requires opposition between individuals and the government. This produces the concept of civil society and public space, criticism towards intellectuals and governments. Therefore, such societies need transparency of the government's decision to balance it. 
In short, Confucian societies are 'top-down' societies, contrasting Christian 'bottom-up' civil society that is consistent with democratic ideals and is also politically correct. Therefore, the perceptions of power various in two types of societies as well.

\section{EMPIRICAL ANALYSIS}

Power is an important aspect discussed in Foucault's later works. In the 1970s Foucault's research changed his focus from "archaeology" to "genealogy". His writings on power mainly appear in Discipline and Punishment: The Birth of the Prison, The History of Sexuality, and in various interviews and lectures. Foucault's analysis of power was even more vivid and distinctive in 1976, in a series of lectures at the College de France that have been compiled and published, this part aims to unravel the power issues in Il Faut Défendre la Société, a compilation of these speeches. From there, this part hopes to analyze Foucault's unique analysis of power.

Foucault believed that there are two dominant theoretical models on the question of power: one is legalpolitical, and the other one is the Marxist model [18]. The former one is represented by the social contract theory that focuses on legal rights. This means that power is regarded as a right that people can own and control like they own and control the property. Since everyone has power, it is fragmented. Therefore, men often fight against each other for their own interests and leading to a state of war. The only way to end such chaos, according to Hobbes, is to bring all fragmented power to a united community, in which its legitimacy is granted by the will of the majority. It is the willingness of a man to relinquish all or part of his interests to benefit from this union to establish a political dominion and accept it [9]. This is the legal-power contract that lays the foundation for the establishment of political power. The formation of political power follows a model that includes the transformation of social contract into legal power. As such, Foucault finds similarities between power and wealth.

Marxists scrutinize and criticize the social contract theory about power, yet, they still see the formation of power relations as the construction of the legal system. Marxists argue that the ruling class has the power to prioritize their interests before others in society [8]. By comparing the formation of power relations to the construction of the legal system, they argue that ownership relations are all attributed to the interests of the economically dominant ruling class, which are ultimately based on a single economic relation and can be deduced from it as well [6]. Therefore, Foucault believes that the Marxist view of power contains economic functionalism, and the main function of power is to maintain the relations of production and to regenerate the rule of class [19]. In this view, one can find the raison d 'être of political power in the economy. This theoretical model still retains the legal system schema, but it replaces the monarch with the economic ruling class and replaces the legal matters with economic matters.

In the above two models, Foucault noticed something in common: the economization of the theory of power. In the Il Faut Défendre la Société, Foucault argues that in one case, one can find the model of political power in the procedure of exchange in the economy. In other cases, political power in the economy has its historical reason to exist, and in the principle of its concrete configurations and from its actual functions as well [20]. Foucault rejects the idea from legal-rights theorists that power can be possessed and transferred like a commodity. He also rejects the idea that power is subordinated to the economy and is driven by economic interests as Marxists analyze [20]. On one hand, the legal-right theorist's view of power takes the perspective of the sovereign power, emphasizing its legitimacy foundation. Although monarch no longer has importance in real politics, it is still preserved in political theory. On the other hand, it is also far-fetched to describe power in economic terms such as transaction, contract, and transfer [6]. The Marxist power analysis theory only ascribes power to the economy and oversimplifies and deals with the complex power relations in a macroscopic way. Therefore, it is weak in explaining micro phenomena such as "sex", "madness" and "imprisonment" [21].

Foucault advocates a non-economic study of power. First, power is not given, exchanged, or compensated, but used. It exists only in concrete actions. Second, the most important function of power is not the maintenance and regeneration of economic relations, but rather a form of power relation. Foucault believes that two hypotheses can be made once if to ignore the economist analysis of power. The first one is that power is oppressive, the second is that power is war. The former holds that power is something that suppresses nature, instinct, other classes, and other people that do not belong to the same group. Many philosophers and scholars like Hegel, Freud, and Wilhelm Reich support this hypothesis. Foucault calls this 'the Reich's hypothesis' [21]. He argues that the analysis of power should be the analysis of its oppressive mechanism due to its oppressive nature, rather than its economic function. The second hypothesis, the 'Nietzsche's hypothesis', holds that the nature of power relations is a conflict between rival powers, a relation of war. In this view, if power itself is the implementation and development of power relations, it is better to analyze it in terms of war and confrontation than in terms of social contract, or the maintenance of relations of production [21]. Such interpretation of political power as war can be supported by reversing Clausewitz's thesis. In his book On War, Clausewitz argues that war is nothing more than the continuation of politics through other means, and it is not only a political act, but also a political tool in real life [22]. Foucault argues that politics is a 
continuous war through various means [23]. This means that, first of all, politics is a confirmation and continuation of the imbalance of power that manifested in war. The goal of political power is not to end the war, nor to try to establish peace within the state, but to create and record power relations formed during the war, and to be kept in the institutional and economic-unequal society. Thus, the existing power relations in society are essentially power relations established at a certain point in history, existed in and inherited through war. Second, Peace is an interlude between wars and conflicts. It is fragmented and is a displacement of war. Within the socalled "civil peace", there are political struggles, power struggles, and changes in power relations, peace is an illusion created by war. The writings of the history of peace and institutions are in fact, history of war and oppression. Finally, only the last war can terminate the operation of power, and only war can be the final arbiter.

However, Reich's hypothesis and Nietzsche's hypothesis can be seen as linked. Repression can be seen as a political consequence of war, and in the classical theories of political power in the 18th century, repression is also seen as an abuse of monarchical power over legal power [24]. The combination of these two hypotheses gave birth to a new power analysis model - the warrepression model, which argues the opposite of what the classical theory of legal power in the eighteenth century does. Among philosophers in the eighteenth century, power was regarded as the birthright of man to be relinquished in the establishment of monarchy [6]. Social contract connects political powers. However, when power extends itself beyond the scope of the social contract, it has the risk of becoming repressive. Foucault regards this mode of analyzing power as a power contract mode, which is a legal mode in which the antagonism is the opposition of legality and illegality. On the contrary, the emerging "war-repression model" no longer seeks to analyze political power in terms of the social contract, rather in terms of war. Here, repression no longer refers to repression related to the social contract, but simply a consequence of the ruling and ruled relation in society. In the false peace produced by continuous war, repression is a way to show this permanent power relation, and confrontation is not antagonism between legality and illegality, but rather lies within victory versus submission.

\section{Chinese scholars' insights on Confucianism}

On the other hand, Chinese scholars often take Confucian values into their theoretical models. Fei Xiaotong, for example, demonstrated this Confucian tradition in his book From the Soil, first published in 1947. In this book, Fei developed a conceptual framework that explains the ethical and moral characteristics in China by contrasting the structure of Chinese society with Western ones.

As mentioned above, Confucianism has the tradition of 'pursuing benevolence' which became the fundamental concept supporting the traditional Chinese centralized system. Traditional Chinese centralized system often struggles and seeks balance between Confucianism and Legalism. Confucianism centralizes the nation on the moral level. The establishment of a political system needs to be legitimized, and without the support of a set of transcendental moral values, it is hard for this centralized system to maintain its legitimacy. Legalism, on the other hand, provides practical governing techniques. Yet, the reason such a centralized system is widely accepted is that the public relies more on the spiritual appeal of "the family, the state and the world" under the Confucian tradition [25]. In addition, after the development of Confucianism by Xunzi, Dong Zhongshu and other Confucian philosophers, it also gradually developed theories that meet the requirements of the centralized system [12].

As mentioned above, Eastern and Western societies have different social structures and governing modes. Western society is based on individual units, with clear rights individual obligations. Thus, forms social groups with clear boundaries. Such a social structure is called the 'organizational mode of association' [2]. In Chinese social relations, individuals are not independent but are reflected as individuals in relationships with others. For example, a man is himself, but at the same time, the husband to his wife, the father to his son, and the son to his father. It is only in these relations that the man becomes a complete individual. Scholars call the phenomenon of interdependence among individuals 'relationship-oriented' social structure, that people seek a sense of security through these relationships [13]. Moreover, relationships are not equal but based on consanguinity or man-made consanguinities such as friends and classmates. Relationships are like spider webs that individuals are at the center of their network. They place others on this web according to their social relations and treat others differently following different social rules and principles. Fei, in his book From the Soil calls this mode of interaction as 'moral order' and 'relation structure' with 'the differential mode of association' [26].

There are three characteristics in terms of power relations derived from this social structure. First, there is a blurred line between public and private rights [27]. In this 'differential mode of association', kinship is the determinate factor of which social rules and social standards to follow when facing different people. At the same time, the kinship-led, or quasi-kinship-led 'differential mode of association' can be extended and adjusted as well. Individuals who are not related by kinship can also build close relationships if they have similar feelings or interests. This flexibility makes it difficult to draw a clear line between the 'public' and 'private' spheres [26]. The formation of a clear public sphere requires equal rights of individuals who are present in this sphere, and their mutual relations should 
have the same principles and rules. Second, there should be a clear line between rights and obligations [28]. However, here in Chinese society, each person has his circle of relations while existing in others' circles. These circles overlap with each other and together, form a complicated relationship among people. Moreover, since individual circles can be extended, everything, in theory, can be regarded as 'private'. Therefore, it is hard to form 'equal rights' and 'uniformed rules'. As a result, there is no clear boundary between private and public.

The result of blurred lines between private and the public is that in the 'relation-based' society, it is highly likely to form unified and monocultural governance. Due to the complex social structure filled with overlapping relationship circles, among circles, individual relation network is hard to be separated from public groups. Therefore, there are no unified rules and although people often interact with each other in the form of small groups, there is no way to make the game transparent and fair for everyone because it is hard to form rules everyone agrees to obey. Even within the same group, members have different social rules and protocols interacting with each other according to social rankings within the group [16]. The result is fierce, irregular conflicts of interests between small groups, each with a sense of insecurity, which is similar to what Hobbes describes as the state of war. As a result, it is inevitable to form a unified supreme authority to integrate and regulate the social structure and rules, to provide social order and good governance. In this system of governance, according to Mencius, the supreme power can only be held by one person, and there can only be one supreme power in the world. This person who holds the highest power has the responsibility and ability to be ultimately responsible for and solve every issue in the world, presenting a form of "omnipotence" politics [15]. At the same time, the social structure is based on the relationship circle of the individual who holds the highest power, and other personal relation circles are based on this, thus laying the foundation for the whole social order and rules.

In addition, under the relation of differential order pattern, the highest power holder in the unified governance model is endowed with moral responsibility and ethical constraints [3]. The social structure under the differential pattern is easy to form a centralized governance model, which concentrates the highest power in the hands of one person [16]. In the 'benevolence' tradition, only the person with the highest moral character, namely "benevolence", can hold the power. The reason why a person can hold the highest power is that his legitimacy comes from his moral cultivation being higher than others in society. In the ancient Greek tradition of "seeking knowledge", only the "king of philosophy" with the highest level of knowledge was supposed to be the king and hold the highest power. Therefore, in the ideal state of the traditional governance model of "benevolence", a "sage" with the highest moral level and the strongest practical ability holds the highest power. He is kind, does what he says and has the spirit of sacrifice, and leads everyone to jointly build a better society [15]. Although such a situation is difficult to achieve, the power of the people and their moral level is not necessarily related, the traditional ideal governance model of "pursuing benevolence" tries to give all rulers a bridle, so that they cannot use power freely and recklessly, but need to follow the corresponding norms and rules. At the same time, the rulers of all dynasties tried to seek the legitimacy and justification of their own rule from this ideal model [15]. Therefore, the traditional ideal governance model of "seeking benevolence" gives the rulers constraints, on the other hand, gives them support.

\section{CONCLUSION}

In conclusion, this essay has discussed how Western mainstream IR theories are stemmed from Christian traditions and how Christian is secularised to a more acceptable form. This essay also compares Confucianism with Christian and showed how these two traditions influenced the West and the East differently in that there are different interpretations and practices of political power. Finally, this essay examined Foucault's work and Fei Xiaotong as empirical analyses to demonstrate the differences. It would provide a clearer picture for the comparative study of oriental and European model of power, sovereignty and political theories.

\section{REFERENCES}

[1] Wang, Y., 2003. The Nationality of International Relations Theory, American studies, vol. 4, pp. 2-7.

[2] Pohl, K.-H., 2002. "Chinese and Western Values: Reflections on a Cross-Cultural Dialogue on a Universal Ethics. Germany, Trier University.

[3] Ho, B. T. E., 2019. Chinese Thinking about International Relations: From Theory to Practice. Asia Policy, 30 July, 14(3), pp. 2-5.

[4] Hoffmann, S., 1977. An American Social Science: International Relations. Daedalus, 3(106), pp. 4160 .

[5] Pohl, K.-H., 2012. The Chinese And Western Values: Reflections On The Methodology of a Crosscultural Dialogue. This Globalizing World, pp. 95103.

[6] Petterson, C., 2012. Colonial subjectification: Foucault, Christianity, and governmentality. Cultural Studies Review, 2(18), pp. 89-108.

[7] Rostow, W. W., 1959. The Stages of Economic Growth. Economic History Review, 12(1), pp. 1-16.

[8] Kim, Y., 1999. A Common Framework for the Ethics of the 21st Century. Paris, UNESCO. 
[9] Hobbes, T., 1588-1679 [2014]. Leviathan. Hertfordshire: Wordsworth Editions Limited.

[10] Rousseau, J.-J., 1755 [2004]. Discourse on the Origin of Inequality. New York: Dover Publication.

[11] Locke, J., 1632-1704 [2002]. The Second Treatise of Government and A Letter Concerning Toleration. New York: Dover Publications.

[12] Hahm, C., 1999/2000. Confucianism and Western Rights: Conflict or Harmony? The Responsive Community. Rights and Responsibilities, 10(1), pp. 55-67.

[13] Sundararajan, L., 2020. A History of the Concepts of Harmony in Chinese Culture. Oxford Research Encyclopedia of Psychology, 28 February.

[14] Kryukov, V., 2009. Symbols of power and communication in pre-Confucian China (on the anthropology of de) preliminary assumptions. Bulletin of the School of Oriental and African Studies, 5 February, 2(58), pp. 314-333.

[15] Yan, Y., 2015. Moral hierarchy and social egoism in a networked society: the chaxugeju thesis revisited. Korean Journal of Sociology, 3(49), pp. 39-58.

[16] Smart, A., 1999. Expressions of interest: friendship and guanxi in Chinese societies. In: S. Bell \& S. Coleman, eds. The Anthropology of Friendship. Oxford: Berg, pp. 119-136.

[17] Rosemont, H., 1991. Rights-bearing individuals and role-bearing persons. In: M. H. Bockover, ed. Rules, Rituals, and Responsibility: Essays Dedicated to Herbert Fingarette. La Salle: Open Court, pp. 71101.

[18] Dreyfus, H. L. \& Rabinow, P., 1982. Michel Foucault: Beyond Structuralism and Hermeneutics. Brighton: Harvester Press.

[19] Sun, X., 2014. The Dilemma of Transcendence: Foucault's Political View of Rights. Quest, Issue 5, pp. 26-31.

[20] Rabinow, P., 1991. The Foucault Reader: An introduction to Foucault's thought. London: Penguin.

[21] Keat, R., 1986. The Human Body in Social Theory: Reich, Foucault and the Repressive Hypothesis. Radical Philosophy, Issue 42, pp. 1-24.

[22] Bassford, C., 1994. Clausewitz in English: The Reception of Clausewitz in Britain and America. Oxford: Oxford University Press.

[23] Foucault, M., 1976. Il Faut Défendre la Société. Seuil: Gallimard.
[24] Foucault, M., 1991. Discipline and Punishment: the Birth of a Prison. London: Penguin.

[25] Fung, Y.-1., 1962. The Spirit of Chinese Philosophy. London: Routledge.

Gaventa, J., 2003. Power after Lukes: a review of the literature. Bringhton: Institute of Development Studies.

[26] Fei, X., 1992. From the Soil: The Foundations of Chinese Society. Berkeley: University of California Press.

[27] Barbalet, J., 2021. The Analysis of Chinese Rural Society: Fei Xiaotong Revisited. Modern China, 4(47), pp. 355-382.

[28] Hamilton, G. G., 2015. What Western social scientists can learn from the writings of Fei Xiaotong. Journal of China in Comparative Perspective, 1(1), pp. 107-127. 